\title{
Penicillinase-resistant Penicillins and Cephalosporins
}

\author{
MARY BARBER,* M.D.; PAMELA M. WATERWORTH,*† F.I.M.L.T.
}

Brit. med. F., 1964, 2, 344-349

The discovery of penicillinase-resistant penicillins is an important landmark in the history of antibacterial chemotherapy. Methicillin came into clinical use in 1960, and its value in the treatment of penicillin-resistant staphylococcal infection is now well established. The same is true of the isoxazolyl penicillins, oxacillin and cloxacillin, which came on to the scenes about a year later. Numerous other penicillinase-resistant penicillins have now been synthesized. Preliminary studies of two of these, nafcillin (Rosenman and Warren, 1961 ; Yurchenco et al., 1961) and ancillin (Dolan, Bondi, et al., 1961 ; Dolan, Rhodes, et al., 1961 ; and Farquhar et al., 1962) were reported at the First Interscience "Conference on Antimicrobial Agents and Chemotherapy in Chicago in 1961. Later a report on a third, quinacillin, appeared (Richards et al., 1963).

In addition, it has been shown that derivatives of cephalosporin $\mathrm{C}$ are resistant to staphylococcal penicillinase while in many other ways resembling the penicillins. The nucleus of cephalosporin C, 7-aminocephalosporanic acid, which has now been isolated, is closely related to the penicillin nucleus, 6-aminopenicillanic acid, but differs from the latter in having a fused dihydrothiazine $\beta$-lactam ring instead of a fused thiazolidine $\beta$-lactam ring. A series of compounds have been prepared by adding different side-chains, as with the semisynthetic penicillins. Several of these have high activity against most penicillin-sensitive bacteria and the penicillinaseproducing staphylococci, and also moderate activity against some coliform bacilli. Studies of one of these, cephalothin, were reported at the Second Interscience Conference on Antimicrobial Agents and Chemotherapy in Chicago in 1962 (Anderson and Petersdorf, 1962 ; Walters et al., 1962).

The present investigation is a comparative study of the antibacterial activity of the five penicillinase-resistant penicillins mentioned above, together with cephalothin and the thienylacetamido cephalosporanic acid in which the acetoxy 3 has been replaced by a pyridine group.

\section{Materials and Methods}

\section{Antibiotics}

The following antibiotics were studied: Penicillins

\begin{tabular}{|c|c|c|}
\hline Side-chain (based on penicillanic acid) & $\begin{array}{l}\text { Accepted } \\
\text { Name }\end{array}$ & $\begin{array}{c}\text { Other } \\
\text { Designations }\end{array}$ \\
\hline $\begin{array}{l}\text { 6-2' : 6'-Dimethoxybenzamido- } \\
\text { 6-(3'-0-Chlorophenyl-5'-methyl) isoxazole- } \\
\text { 4'-carboxamido- } \\
\text { 2-Ethoxy-1-naphthamido- } \\
\text { 2-Biphenyl- } \\
\text { 3-Carboxyquinoxaline-2-yl- }\end{array}$ & $\begin{array}{l}\text { Methicillin } \\
\text { Cloxacillin } \\
\text { Nafcillin } \\
\text { Ancillin } \\
\text { Quinacillin }\end{array}$ & $\begin{array}{l}\text { Celbenin } \\
\text { Staphcillin } \\
\text { Orbenin } \\
\text { Wy.3277 } \\
\text { Sk\&F.1241 } \\
\text { RD.13962 }\end{array}$ \\
\hline
\end{tabular}

\begin{tabular}{c|c|c}
\hline \multicolumn{3}{c}{ Cephalosporins } \\
\hline $\begin{array}{c}\text { Side-chain } \\
\text { (based on 7-Aminocephalosporanic acid) }\end{array}$ & $\begin{array}{c}\text { Accepted } \\
\text { Name }\end{array}$ & $\begin{array}{c}\text { Other } \\
\text { Designations }\end{array}$ \\
\hline 7-(Thiophene-2-acetamido) & Cephalothin & $87 / 1$ \\
\hline
\end{tabular}

We are grateful to Beecham Laboratories for supplies of methicillin and cloxacillin; to John Wyeth and Brother for nafcillin; to Smith Kline and French Laboratories for ancillin; to Boots Pure Drug Company for quinacillin ; and to Glaxo Laboratories for cephalothin and its pyridine salt.

Bacteriostatic Tests.- These were carried out by preparing doubling dilutions of the antibiotic in nutrient agar. The inoculum was made with a standard 1-mm. loop from an overnight broth culture; except where otherwise stated, the culture was first diluted 1 in 500. For tests of serum binding pooled human serum was used.

Bactericidal Tests.-Bactericidal activity was tested by the cellophane transfer technique of Chabbert (1957), full details of which are described by Garrod and Waterworth (1962).

Development of Resistance.-Representative coliform bacilli were passaged on ditch-plates containing each of the two cephalosporins and then tested for their sensitivity to these antibiotics and penicillin.

Estimation of Penicillinase and Cephalosporinase.-Tests were carried out on whole cultures by the iodometric method of Perret (1954).

Identification of Species.-This was done on the basis of the diagnostic tables of Cowan and Steel (1961).

\section{Antistaphylococcal Activity}

The activity of the antibiotics against a number of penicillinsensitive and penicillinase-producing strains of Staphylococcus

Table I.-Activity Against Staph. aureus

\begin{tabular}{l|l|l|l|l|l|l|l|l}
\hline & $\begin{array}{c}\text { No. of } \\
\text { Strains } \\
\text { Tested }\end{array}$ & \multicolumn{5}{|c}{ No. of Strains Inhibited by ( $\mu \mathrm{g} . / \mathrm{ml})}$. \\
\cline { 2 - 8 } & 0.06 & 0.12 & 0.25 & 0.5 & 1 & 2 & .4 \\
\hline
\end{tabular}

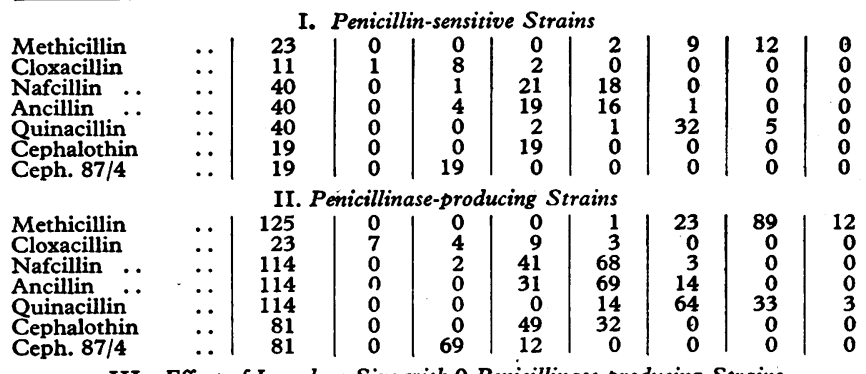

III. Effect of Inoculum Size with 9 Penicillinase-producing Strains

\begin{tabular}{|c|c|c|c|}
\hline & & $\begin{array}{l}\text { Fold Increase in } \\
\text { M.I.C. with Large } \\
\text { Inoculum }\end{array}$ & $\begin{array}{c}\text { Concentration Inhibiting } \\
\text { Large Inoculum of } \\
\text { All Strains }\end{array}$ \\
\hline $\begin{array}{l}\text { Methicillin } . . \\
\text { Cloxacillin } . \\
\text { Nafcillin } \\
\text { Ancillin } \\
\text { Quinacillin } . \\
\text { Cephalothin } \\
\text { Ceph. 87/4 .. }\end{array}$ & $\begin{array}{l}\ldots \\
\because \\
\because \\
\because \\
\cdots\end{array}$ & $\begin{array}{l}0-2 \\
2-4 \\
2-4 \\
2-4 \\
0-2 \\
2 \\
2-16\end{array}$ & $\begin{array}{l}4 \\
1 \\
1 \\
1 \\
2 \\
1 \\
1 \\
2\end{array}$ \\
\hline
\end{tabular}

aureus tested with the standard inoculum is given in Table I. It will be seen that ceph $87 / 4$ had the most consistently high activity, and inhibited all of 100 strains (19 penicillinsensitive and 81 penicillinase-producing) in a concentration

- From the Department of Bacteriology, Postgraduate Medical School of London.

+ Working with a full-time grant from the Medical Research Council. 
of 0.12 or $0.25 \mu \mathrm{g} . / \mathrm{ml}$. Cloxacillin had a similarly high activity, but there was more scatter. Methicillin and quinacillin showed the least activity.

\section{Effect of Inoculum Size with Penicillin-producing Staphylococci}

When penicillinase-producing strains are tested for their sensitivity to benzylpenicillin the results vary many hundredfold with the size of inoculum, since a large inoculum contains enough ready-made penicillinase to inactivate quite large concentrations of penicillin. Bacteriostatic tests were therefore carried out with both the standard inoculum (loopful of 1 in 500 dilution of broth culture) and an inoculum 500 times larger-that is, loopful of neat culture. The fold increases in minimum bacteriostatic concentration with the large inoculum, together with the concentration of each antibiotic inhibiting the large inoculum of all strains, are given in the last section of Table I. It will be seen that methicillin and quinacillin were the least affected by inoculum size and ceph. 87/4 the most.

Methicillin-resistant Strains.-The comparative sensitivity of 10 naturally occurring methicillin-resistant strains of Staph. aureus was studied. Tests were carried out with a small and large inoculum, since it is well known that the sensitivity of such strains to methicillin varies considerably with the size of inoculum. Representative results with five strains are given

TABLE II.-Activity Against Methicillin-resistant Strains of Staph.

\begin{tabular}{|c|c|c|c|c|c|c|}
\hline & \multicolumn{6}{|c|}{ Minimum Inhibitory Concentration ( $\mu \mathrm{g} . / \mathrm{ml}$.) } \\
\hline & $\begin{array}{l}\text { Methi- } \\
\text { cillin }\end{array}$ & $\begin{array}{l}\text { Naf- } \\
\text { cillin }\end{array}$ & $\begin{array}{l}\text { An- } \\
\text { cillin }\end{array}$ & $\begin{array}{l}\text { Quina- } \\
\text { cillin }\end{array}$ & $\mid \begin{array}{c}\text { Cephal- } \\
\text { othin }\end{array}$ & Ceph. \\
\hline \multicolumn{7}{|c|}{ Naturally Occurring Strains } \\
\hline P.6 $\left\{\begin{array}{l}\text { Small inozulum } \\
\text { Large inoculum }\end{array}\right.$ & $\begin{array}{r}8 \\
128\end{array}$ & $\begin{array}{r}8 \\
64\end{array}$ & 32 & $\begin{array}{l}256 \\
512\end{array}$ & $\begin{array}{r}8 \\
64\end{array}$ & $\begin{array}{r}2 \\
16\end{array}$ \\
\hline $\begin{array}{l}\text { Q.M. } \\
3\end{array}\left\{\begin{array}{l}\text { Small inoculum } \\
\text { Large inoculum }\end{array}\right.$ & $\begin{array}{r}32 \\
256\end{array}$ & $\begin{array}{r}32 \\
128\end{array}$ & $\begin{array}{r}8 \\
32\end{array}$ & $\begin{array}{l}>256 \\
>256\end{array}$ & $\begin{array}{l}32 \\
64\end{array}$ & $\begin{array}{r}4 \\
16\end{array}$ \\
\hline M.20 $\left\{\begin{array}{l}\text { Small inoculum } \\
\text { Large inoculum }\end{array}\right.$ & $\begin{array}{l}4 \\
8\end{array}$ & $\begin{array}{l}4 \\
8\end{array}$ & $\begin{array}{l}1 \\
4\end{array}$ & $\begin{array}{l}64 \\
64\end{array}$ & $\begin{array}{r}2 \\
16\end{array}$ & $\begin{array}{l}2 \\
4\end{array}$ \\
\hline H.37 $\left\{\begin{array}{l}\text { Small inoculum } \\
\text { Large inoculum }\end{array}\right.$ & $\begin{array}{r}8 \\
128\end{array}$ & $\begin{array}{r}8 \\
64\end{array}$ & $\begin{array}{l}4 \\
8\end{array}$ & $\begin{array}{r}64 \\
256\end{array}$ & $\begin{array}{r}2 \\
32\end{array}$ & $\begin{array}{r}1 \\
16\end{array}$ \\
\hline M.33 $\left\{\begin{array}{l}\text { Small inoculum } \\
\text { Large inoculum }\end{array}\right.$ & $\begin{array}{r}8 \\
64\end{array}$ & $\begin{array}{r}4 \\
64\end{array}$ & $\begin{array}{r}2 \\
32\end{array}$ & $\begin{array}{r}64 \\
256\end{array}$ & $\begin{array}{r}2 \\
32\end{array}$ & $\begin{array}{r}2 \\
16\end{array}$ \\
\hline \multicolumn{7}{|c|}{ In-vitro-trained Strain } \\
\hline H.18 \{l Small inoculum & $\begin{array}{l}128 \\
128\end{array}$ & $\begin{array}{l}\mathbf{8} \\
\mathbf{8}\end{array}$ & $\begin{array}{l}4 \\
8\end{array}$ & $\begin{array}{l}4 \\
4\end{array}$ & $\begin{array}{l}32 \\
32\end{array}$ & $\begin{array}{l}2 \\
8\end{array}$ \\
\hline
\end{tabular}

in Table II together with those obtained with a strain showing laboratory-induced resistance. It will be seen that the naturally occurring methicillin-resistant strains were about equally resistant to methicillin and nafcillin, and rather less resistant to ancillin and the cephalosporins, but with all these antibiotics the increase in inoculum size caused a similar increase in resistance. Results with quinacillin differed in that all the strains were much more resistant to this penicillin and the inoculum effect was relatively slight.

The sensitivity of the laboratory-trained methicillin-resistant strain was not affected by the size of inoculum except for a fourfold difference with ceph. $87 / 4$ and it was much more resistant to methicillin than to any of the others. It was moderately resistant to cephalothin and slightly resistant to nafcillin, ancillin, and ceph. 87/4. It was no more resistant to quinacillin than are some methicillin-sensitive penicillinaseproducing strains.

\section{Bactericidal Tests}

All the compounds killed a small inoculum of staphylococci within 18 hours in a concentration similar to the minimum bacteriostatic concentration, but none sterilized a large inoculum. It seemed probable that this difference was due to the presence of a few persisters when the large inoculum was used. To test this the degree of kill after seven hours was estimated by the cellophane transfer technique. Tambours were placed on the surface of nutrient agar plates which had been previously treated with filter-paper strips soaked in $500 \mu \mathrm{g} . / \mathrm{ml}$. of the antibiotic to be tested, and the tambours were flooded with serial tenfold dilutions of an overnight broth culture of an active penicillinase-producing strain of Staph. aureus. After seven hours the tambours were transferred to fresh medium and after overnight incubation the surviving colonies in the inhibition zones were counted.

On control medium, not treated with antibiotic strips, the 1 in 10,000 dilution was the first dilution to give discrete colonies and the count at the 1 in 100,000 dilution was about 150. The number of colonies from these dilutions surviving in the inhibition zones of each of the antibiotics is shown in Table III.

\begin{tabular}{|c|c|c|c|c|c|}
\hline & & & & \multicolumn{2}{|c|}{ Dilution } \\
\hline & & & & 1 in 10,000 & 1 in 100,000 \\
\hline $\begin{array}{l}\text { Methicillin } \\
\text { Nafcillin } \\
\text { Ancillin } \\
\text { Quinacillin } \\
\text { Cephalothin } \\
\text { Ceph. 87/4 }\end{array}$ & $\begin{array}{l}\ddot{0} \\
\ddot{0} \\
\ddot{0}\end{array}$ & $\begin{array}{c}\because \\
\because \\
\because \\
\because\end{array}$ & 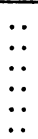 & $\begin{array}{r}5 \\
25 \\
30 \\
30 \\
30 \\
10\end{array}$ & $\begin{array}{l}0 \\
7 \\
1 \\
0 \\
2 \\
1\end{array}$ \\
\hline
\end{tabular}

\section{Effect of Serum on Activity}

Bacteriostatic tests were carried out on an active penicillinaseproducing strain of Staph. aureus in nutrient broth and in $95 \%$ pooled human serum. With both media the standard inoculum and a large inoculum (neat culture) were compared. The fold increases in resistance in $95 \%$ serum are given in Table IV, together with the minimum inhibitory concentra-

TABLE IV.-Effect of Serum on Activity (Tests Done with a Penicillinaseproducing Strain of Staph. aureus)

\begin{tabular}{|c|c|c|c|c|c|c|}
\hline & & & & $\begin{array}{r}\text { Fold Incr } \\
\text { in } 95\end{array}$ & $\begin{array}{l}\text { in M.I.C. } \\
\text { rum }\end{array}$ & $\begin{array}{c}\text { M.I.C. for } \\
\text { Large Inoculum }\end{array}$ \\
\hline & & & & $\underset{\text { Inoculum }}{\text { Small }}$ & $\begin{array}{c}\text { Large } \\
\text { Inoculum }\end{array}$ & $\begin{array}{l}\text { in } 95 \% \\
\text { Serum }\end{array}$ \\
\hline $\begin{array}{l}\text { Methicillin } \\
\text { Cloxacillin } \\
\text { Nafcillin } \\
\text { Ancillin } \\
\text { Quinacillin } \\
\text { Cephalothin } \\
\text { Ceph. 87/4 }\end{array}$ & $\begin{array}{l}\because \\
\because \\
\therefore \\
\therefore\end{array}$ & $\begin{array}{l}\ddot{*} \\
\ddot{0} \\
\ddot{0} \\
\cdots\end{array}$ & $\begin{array}{l}\because \\
\because \\
\because \\
\therefore\end{array}$ & $\begin{array}{l}0 \\
8 \\
4 \\
8 \\
2 \\
2 \\
0\end{array}$ & $\begin{array}{l}0 \\
8 \\
8 \\
8 \\
4 \\
4 \\
0\end{array}$ & $\begin{array}{l}4 \\
4 \\
4 \\
8 \\
4 \\
2 \\
0.5\end{array}$ \\
\hline
\end{tabular}

tions for a large inoculum in $95 \%$ serum. It will be seen that the activity of methicillin and ceph. $87 / 4$ was unaffected by serum. The activity of cloxacillin, nafcillin, and ancillin was considerably reduced, and that of quinacillin and cephalothin moderately. With a large inoculum in $95 \%$ serum ceph. $87 / 4$ was four times as active as any other compound, and all the other compounds were similar in activity.

\section{Effect of $\mathbf{p H}$}

The effect of changes in $\mathrm{pH}$ was studied with the same penicillinase-producing strain of Staph. aureus. Bacteriostatic tests with the standard inoculum were compared in nutrient

TABLE V.-Effect of $p H(p H \underset{\text { in M.I.C. }}{7=1}$. Foldease $(+)$ or Decrease (-)

\begin{tabular}{c|c|c|c|c|c|c|c|c}
\hline$p \mathrm{H}$ & $\begin{array}{c}\text { Benzyl- } \\
\text { peni- } \\
\text { cillin }\end{array}$ & $\begin{array}{c}\text { Methi- } \\
\text { cillin }\end{array}$ & $\begin{array}{c}\text { Cloxa- } \\
\text { cillin }\end{array}$ & $\begin{array}{c}\text { Naf- } \\
\text { cillin }\end{array}$ & $\begin{array}{c}\text { An- } \\
\text { cillin }\end{array}$ & $\begin{array}{c}\text { Quina- } \\
\text { cillin }\end{array}$ & $\begin{array}{c}\text { Cephal- } \\
\text { othin }\end{array}$ & $\begin{array}{c}\text { Ceph. } \\
87 / 4\end{array}$ \\
\hline 6.0 & 1 & +2 & +2 & +2 & +2 & +2 & +2 & -2 \\
6.5 & 1 & +2 & +2 & 1 & 1 & -1 & +2 & 1 \\
7.5 & -2 & +2 & -2 & 1 & 1 & -2 & 1 & +2 \\
$8 \cdot 0$ & -2 & -2 & -2 & 1 & -2 & -4 & 1 & +2 \\
8.5 & -2 & -2 & -2 & 1 & -2 & -4 & 1 & +2 \\
\hline
\end{tabular}


broth at $\mathrm{pH} 6,6.5,7,7.5,8$, and 8.5. Taking the results with pH 7 as unity, the fold increase or decrease at other $p H s$ is given in Table V. It will be seen that the activity of most of the compounds was slightly favoured by acidity and slightly reduced in an alkaline medium. The position with ceph. 87/4 was reversed.

\section{Activity Against Other Bacteria}

\section{Gram-positive Bacteria}

The bacteriostatic activity of the antibiotics against various Gram-positive bacteria tested with the standard inoculum are given in Table VI. Against Streptococcus pyogenes and Streptococcus pneumoniae all the antibiotics tested, except quinacillin, showed high activity; ceph. 87/4 was the most active.

With Bacillus anthracis, which is a penicillinase-producing organism, methicillin and ceph. $87 / 4$ showed similar high activity and were the most active compounds tested. Quinacillin was again the least active, and indeed the strains were fairly resistant to this compound.

None of the compounds showed high activity against Str. faecalis, but quinacillin was among the more active compounds and against some strains of this species had the highest activity.

\section{Neisseria and $\mathbf{H}$. influenzae}

The minimum inhibitory concentrations for strains of Neisseria and Haemophilus influenzae are given in Table VII. Strains of $N$. gonorrhoeae are divided into three groups according to their sensitivity to benzylpenicillin, and it will be seen that strains with increased resistance to benzylpenicillin were also more resistant to the other antibiotics. Against the penicillin-sensitive strains methicillin showed an activity only slightly less than that of benzylpenicillin and was much more active than any of the other compounds. Ceph. 87/4 showed the lowest activity.

With $N$. catarrhalis and $N$. meningitidis the differences in activity between the new antibiotics were smaller, although again none was as active at benzylpenicillin. Nafcillın and ancillin were the most active against $N$. catarrhalis and cephalothin was the most active against $N$. meningitidis.

Methicillin and cephalothin were the most effective against $H$. influenzae and showed about a quarter to half the activity of benzylpenicillin. Quinacillin was the least effective against this species.

\section{Coliform Bacilli}

Results obtained in similar tests with a number of strains of coliform bacilli are shown in Table VIII. Ampicillin was included in the tests for comparative purposes. It will be seen that none of the penicillins, except ampicillin, showed any significant activity against any of the strains tested.

The two cephalosporins, however, showed a similar activity to that of ampicillin against most species and greater activity against some strains of Proteus and Klebsiella spp. The most noticeable difference between ampicillin and the cephalosporins was in relation to penicillinase-producing strains of Proteus mirabilis. These strains were all highly resistant to ampicillin, but were as sensitive to the cephalosporins as were the penicillinase-negative strains. The cephalosporins were also more active than ampicillin against most strains of Klebsiella spp. The two strains of Enterobacter aerogenes tested were highly resistant to all three antibiotics.

TABLE VI.-Activity Against Gram-positive Bacteria

\begin{tabular}{|c|c|c|c|c|c|c|c|c|c|c|c|}
\hline . & & & & \multirow{2}{*}{$\begin{array}{l}\text { No. of } \\
\text { Strains }\end{array}$} & \multicolumn{7}{|c|}{ Minimum Inhibitory Concentration ( $\mu \mathrm{g} . / \mathrm{ml}$ ) } \\
\hline & & & & & Methicillin & Cloxacillin & Nafcillin & Ancillin & Quinacillin & Cephalothin & Ceph. 87/4 \\
\hline $\begin{array}{l}\text { Staph. pyogenes } \\
\text { Str. pyogenes ... } \\
\text { Str. pneemonomiae } \\
\text { Str. faecalis .. } \\
\text { B. anthracis .. }\end{array}$ & $\begin{array}{c}\text { Pen. } \\
\text { Pen. } \\
\therefore \\
\therefore \\
\therefore\end{array}$ & $\begin{array}{l}\cdots \\
\because \\
\cdots\end{array}$ & $\begin{array}{l}\cdots \\
\therefore \\
\ddot{0} \\
\therefore\end{array}$ & $\begin{array}{l}\overline{-} \\
14 \\
16 \\
15 \\
13\end{array}$ & $\begin{array}{c}0.5-2 \\
0.5-4 \\
0.125 \\
0.25 \\
16-32 \\
0.06-0.12\end{array}$ & $\begin{array}{c}0.06-0.25 \\
0.06-0.5 \\
0.06 \\
0.12-0.25 \\
32-64 \\
0.5\end{array}$ & $\begin{array}{c}0.25-0.5 \\
0.25-1 \\
0.03-0.06 \\
0.03-0.06 \\
8 \\
0.5\end{array}$ & $\begin{array}{c}0.12-0.5 \\
0.25-1 \\
0.12 \\
0.06-0.25 \\
8-16 \\
0.25-0.5\end{array}$ & $\begin{array}{l}0 \cdot 5-1 \\
0 \cdot 2-2 \\
4-8 \\
0 \cdot 5-2 \\
4-16 \\
32-64\end{array}$ & $\begin{array}{c}0.25-0.5 \\
0.25-1 \\
0.06 \\
0.06-0.12 \\
32 \\
0.25-0.5\end{array}$ & $\begin{array}{c}0.12 \\
0.12-0.25 \\
0.007 \\
0.015-0.03 \\
8-16 \\
0.06-0.12\end{array}$ \\
\hline
\end{tabular}

* See Table II.

TABLE VII.-Activity Against Neisseria and H. influenzae

\begin{tabular}{|c|c|c|c|c|c|c|c|c|c|c|}
\hline & & \multirow{2}{*}{$\underset{\text { penicillin }}{\text { Benzyl- }}$} & \multirow{2}{*}{$\begin{array}{l}\text { No. of } \\
\text { Strains }\end{array}$} & \multicolumn{7}{|c|}{ Minimum Inhibitory Concentration ( $\mu \mathrm{g} . / \mathrm{ml})}$. \\
\hline & & & & Methicillin & Cloxacillin & Nafcillin & Ancillin & Quinacillin & Cephalothin & Ceph. 87/4 \\
\hline $\begin{array}{l}\text { N. gonorrhoeae } \\
\text { N. catarrhalis .. } \\
\text { N. meningitidis . } \\
\text { H. influenzae . }\end{array}$ & $\begin{array}{c}\cdots \\
\quad \ldots \\
\quad \cdots\end{array}$ & $\begin{array}{c}0.015-0.03 \\
0.06-0.12 \\
0.5 \\
0.03 \\
0.03 \\
0.25-4.0\end{array}$ & $\begin{array}{r}20 \\
2 \\
3 \\
7 \\
2 \\
12\end{array}$ & $\begin{array}{l}0.03-0.06 \\
\overline{2-4} \\
0.12-0.25 \\
0.25-2 \\
1-8\end{array}$ & $\begin{array}{c}0.75-0.5 \\
>- \\
0.25-2 \\
0.25-1 \\
8-32\end{array}$ & $\begin{array}{c}0.5-1 \\
2 \\
16 \\
0.06-0.5 \\
0.5 \\
4-32\end{array}$ & $\begin{array}{c}0.5-1 \\
2 \\
16 \\
0.06-0.5 \\
1 \\
2-16\end{array}$ & $\begin{array}{c}1 \\
4-8 \\
32 \\
0 \cdot 25-1 \\
1 \\
64-256\end{array}$ & $\begin{array}{c}0.25-0.5 \\
0.5-1 \\
1-2 \\
0.12-0.5 \\
0.12-0.5 \\
2-8\end{array}$ & $\begin{array}{c}4 \\
4 \\
8-16 \\
0 \cdot 12-1 \\
0.5-1 \\
4-16\end{array}$ \\
\hline
\end{tabular}

Table VIII.-Activity Against Coliform Bacilli

\begin{tabular}{|c|c|c|c|c|c|c|c|c|c|c|c|c|}
\hline & & & & \multirow{2}{*}{$\begin{array}{l}\text { No. of } \\
\text { Strains }\end{array}$} & \multicolumn{8}{|c|}{ Minimum Inhibitory Concentration ( $\mu \mathrm{g} . / \mathrm{ml})}$. \\
\hline & & & & & Methicillin & Cloxacillin & Nafcillin & Ancillin & Quinacillin & Cephalothin & Ceph. 87/4 & Ampicillin \\
\hline $\begin{array}{l}\text { Escherichia coli } \\
\text { Salmonella typhi } \\
\text { Salmonella spp. } \\
\text { Shigella flexneri } \\
\text { Sh. sonnei } \\
\text { Pr. mirabilis (a.) } \\
\text { Pr. vulgaris } \\
\text { Pr. rettgeri } \\
\text { Pr. morgani } \\
\text { Ki. edwardsii } \\
\text { Kl. aerogenes } \\
\text { Ent. aerogenes }\end{array}$ & $\begin{array}{l}\because \\
\because \\
\because \\
\because \\
\because \\
\because \\
\therefore \\
\therefore\end{array}$ & $\begin{array}{l}\because \\
\because \\
\because \\
\because \\
\therefore \\
\therefore \\
\because \\
\therefore\end{array}$ & $\begin{array}{l}\because \\
\because \\
\cdots \\
\cdots \\
\therefore \\
\cdots \\
\cdots\end{array}$ & $\begin{array}{r}14 \\
7 \\
11 \\
5 \\
2 \\
6 \\
6 \\
7 \\
10 \\
7 \\
8 \\
9 \\
2\end{array}$ & $\begin{array}{c}512-<512 \\
512 \\
256-512 \\
512->512 \\
512->512 \\
128-512 \\
512->512 \\
256->512 \\
64->512 \\
256->512 \\
= \\
=\end{array}$ & $\begin{array}{c}128-512 \\
256-512 \\
256-512 \\
64-512 \\
256-512 \\
512->512 \\
512->512 \\
64-256 \\
512->512 \\
= \\
=\end{array}$ & $\begin{array}{c}512-<512 \\
512 \\
512 \\
128-256 \\
512 \\
512 \\
512 \\
512 \\
64-512 \\
512 \\
= \\
=\end{array}$ & $\begin{array}{c}256-512 \\
256 \\
512 \\
128 \\
512 \\
512->512 \\
512->512 \\
512 \\
64-256 \\
512->512 \\
= \\
=\end{array}$ & $\begin{array}{c}512 \\
512 \\
512 \\
512 \\
512 \\
512->512 \\
512 \\
512->512 \\
128->256 \\
512->512 \\
= \\
-\end{array}$ & $\begin{array}{c}2-8 \\
0.5-2 \\
2-4 \\
1-2 \\
4-8 \\
4-8 \\
4-8 \\
64->256 \\
2->512 \\
256 \\
1-4 \\
2-32 \\
128-256\end{array}$ & $\begin{array}{c}2-4 \\
2 \\
2-4 \\
1-2 \\
1-2 \\
8 \\
8 \\
128->256 \\
2->256 \\
256->256 \\
1-4 \\
2-8 \\
128-256\end{array}$ & $\begin{array}{c}2-8 \\
0 \cdot 5-1 \\
1-4 \\
4 \\
8 \\
2-8 \\
512->512 \\
16->128 \\
32-512 \\
32->512 \\
8-128 \\
32->256 \\
>256\end{array}$ \\
\hline
\end{tabular}




\section{Effect of Inoculum Size on Sensitivity of Proteus and Aerobacter to the Cephalosporins}

Since Proteus and Klebsiella spp. produce penicillininactivity enzymes, bacteriostatic tests with strains of these groups were carried out using a small and large inoculum. Parallel tests were carried out with benzylpenicillin. The results are given in Table IX.

With the penicillinase-producing strains of $\mathrm{Pr}$. mirabilis there was a marked difference between the effect of inoculum size on sensitivity to benzylpenicillin and the cephalosporins. With benzylpenicillin the large inoculum caused a thirtyfold to over a hundredfold increase in resistance, although even with a very small inoculum all strains were resistant to $250 \mu \mathrm{g}$. of benzylpenicillin or ampicillin per $\mathrm{ml}$. With the cephalosporins the small inoculum of all strains was sensitive to $8 \mu \mathrm{g} . / \mathrm{ml}$. and the increase in minimum inhibitory concentration with the large inoculum was only twofold with cephalothin and fourfold to eightfold with ceph. 87/4, a difference not much greater than that found with penicillinase-negative strains.

With Pr. rettgeri the position was reversed in that the effect of inoculum was greater with ceph. 87/4 than with benzylpenicillin ; but, with this species, most strains showed a high degree of resistance to both antibiotics even when tested with a small inoculum.

Strains of $\mathrm{Pr}$. vulgaris were highly resistant to both compounds even with a small inoculum, but in both cases there was an increase of eightfold or more with the large inoculum. Strains of Pr. morgani were even more highly resistant to both compounds, and the minimum inhibitory concentrations were almost as great with the small inoculum as with the large.

With benzylpenicillin the strains of Klebsiella tested were all moderately or highly resistant even with a small inoculum and showed a sixteenfold to thirty-two-fold increase in resistance with the large inoculum. All the strains were much more sensitive to the cephalosporins, and with these antibiotics the effect of inoculum size was variable. Three of the 16 strains of $K l$. aerogenes and all three of $K l$. edwardsii remained moderately sensitive even with a large inoculum, but three strains of $\mathrm{Kl}$. aerogenes showed a thirty-two-fold inoculum effect with both cephalosporins.

\section{Passage of Coliform Bacilli in Benzylpenicillin and Ceph. 87/4}

Representative strains of $\mathrm{Pr}$. mirabilis, $\mathrm{Kl}$. aerogenes, and $E$. coli were passaged separately in benzylpenicillin and ceph. 87/4. After 12 passages the sensitivity of the resulting cultures to two antibiotics was compared with that of the original strains. With one strain of each species the parent and passaged cultures were tested for their penicillinase activity by the iodometric method. The results are given in Table X. It will be seen that all strains showed a considerable increase in resistance to the antibiotic in which they had been passaged and a moderate increase in resistance to the other antibiotic. With the Klebsiella spp. this was associated with an increase in penicillinase and cephalosporinase activity, particularly after passage in benzylpenicillin. With the other species there was no change in this type of enzyme activity, and the penicillinasepositive strains of Pr. mirabilis failed to show any significant cephalosporinase activity after passage in spite of a sixteenfold to thirty-two-fold increase in resistance.

\section{Discussion}

\section{Antistaphylococcal Activity}

From the therapeutic point of view the most important feature of these antibiotics is their activity against Staph. aureus. None is as active as benzylpenicillin against penicillinsensitive staphylococci, but all show almost equal activity against penicillin-sensitive and penicillinase-producing strains. In tests on nutrient agar with a moderate or small inoculum the order of activity was ceph. 87/4, cloxacillin, then

TABLE IX.-Effect of Inoculum Size on Sensitivity of Proteus and Aerobacter spp. to the Cephalosporins and Benzylpenicillin

\begin{tabular}{|c|c|c|c|c|c|c|c|c|c|c|c|c|}
\hline & & & & & \multirow{2}{*}{$\begin{array}{l}\text { No. of } \\
\text { Strains }\end{array}$} & \multicolumn{4}{|c|}{ Minimum Inhibitory Concentration ( $\mu \mathrm{g} \cdot / \mathrm{ml})}$. & \multicolumn{3}{|c|}{ Fold Increase with Large Inoculum } \\
\hline & & & & & & Inoculum & Cephalothin & Ceph. 87/4 & $\begin{array}{c}\text { Benzyl- } \\
\text { penicillin }\end{array}$ & Cephalothin & Ceph. 87/4 & $\begin{array}{l}\text { Benzyl- } \\
\text { penicillin }\end{array}$ \\
\hline \multicolumn{5}{|c|}{ Pr. mirabilis (a) penicillinase-positive } & 4\{ & $\begin{array}{l}\text { Neat } \\
1 / 500\end{array}$ & $\begin{array}{l}16 \\
4-8\end{array}$ & $32-64$ & $\begin{array}{c}10,000-20,000 \\
300-600\end{array}$ & $2-4$ & $4-8$ & $\overline{32-120}$ \\
\hline \multicolumn{5}{|c|}{ Pr. mirabilis (b) penicillinase-negative . } & 6\{ & $\begin{array}{l}\text { Neat } \\
1 / 500\end{array}$ & $\bar{z}$ & $\begin{array}{l}16-32 \\
8-16\end{array}$ & $\begin{array}{l}8-16 \\
4-16\end{array}$ & - & $2-4$ & $0-2$ \\
\hline Pr. rettgeri* & . & . & $\cdot \cdot$ &. & 3\{ & $\begin{array}{l}\text { Neat } \\
1 / 500\end{array}$ & 二 & $\begin{array}{l}2,000 \\
128-256\end{array}$ & $\begin{array}{r}1,200-5,000 \\
300-1,200\end{array}$ & - & $8-16$ & $2-4$ \\
\hline Pr. vulgaris & .. & .. & . & .. & 5\{ & $\begin{array}{l}\text { Neat } \\
1 / 500\end{array}$ & $\overline{-}$ & $\begin{array}{l}2,000-4,000 \\
64-500\end{array}$ & $\begin{array}{c}2,000 \\
250-1,000\end{array}$ & - & $8-32$ & 8 \\
\hline Kl. edwardsii & . & . & . & $\cdots$ & 3\{ & $\begin{array}{l}\text { Neat } \\
1 / 500\end{array}$ & $\begin{array}{l}4-16 \\
1-4\end{array}$ & $\begin{array}{l}2-8 \\
1-4\end{array}$ & $\begin{array}{l}8-500 \\
2-32\end{array}$ & 2-8 & $0-4$ & $2->16$ \\
\hline Kl. aerogenes & .. & .. & .. & .. & 6\{ & $\begin{array}{l}\text { Neat } \\
1 / 500\end{array}$ & ${ }_{2-4}^{16-128}$ & $\begin{array}{r}4-128 \\
32-300\end{array}$ & $300-5,000$ & $8-32$ & $2-32$ & $16-32$ \\
\hline
\end{tabular}

TABLE X.-Effect of Passage of Coliform Bacilli in Benzylpenicillin of Ceph. 87/4

\begin{tabular}{|c|c|c|c|c|c|c|c|c|c|}
\hline \multirow{2}{*}{\multicolumn{4}{|c|}{ Species }} & \multirow{2}{*}{$\begin{array}{l}\text { No. of } \\
\text { Strains }\end{array}$} & \multirow{2}{*}{$\begin{array}{l}\text { Antibiotic } \\
\text { for Passage }\end{array}$} & \multicolumn{2}{|c|}{ Minimum Inhibitory Concentration ( $\mu \mathrm{g} . / \mathrm{ml})}$. & \multicolumn{2}{|c|}{ Enzyme Activity ( $\mu \mathrm{mol} / \mathrm{ml}) *}$. \\
\hline & & & & & & Benzylpenicillin & Ceph. 87/4 & Penicillinase & Cephalosporinase \\
\hline \multicolumn{4}{|c|}{ Pr. mirabilis (a) penicillinase-negative } & 2 & $\begin{array}{l}\text { Nil } \\
\text { Penicillin } \\
\text { Ceph. 87/4 }\end{array}$ & $\begin{array}{c}4-8 \\
64-128 \\
32\end{array}$ & $\begin{array}{c}4-8 \\
32-64 \\
128-256\end{array}$ & $\begin{array}{l}<0.1 \\
<0.1 \\
<0.1\end{array}$ & $\begin{array}{l}<0.2 \\
<0.2 \\
<0.2\end{array}$ \\
\hline \multicolumn{4}{|c|}{ Pr. mirabilis (b) penicillinase-positive } & 2 & $\begin{array}{l}\text { Nil } \\
\text { Penicillin } \\
\text { Ceph. 87/4 }\end{array}$ & $\frac{512}{>512}$ & $\frac{8}{128-256}$ & $\frac{13.0}{14.5}$ & $\frac{0.4}{0.4}$ \\
\hline$K l$. aerogenes & $\cdots$ & $\cdots$ & $\cdots \quad \cdots$ & 2 & $\begin{array}{l}\text { Nil } \\
\text { Penicillin } \\
\text { Ceph. 87/4 }\end{array}$ & $\begin{array}{c}32-64 \\
64-512 \\
256\end{array}$ & $\begin{array}{c}2-4 \\
4-16 \\
128-256\end{array}$ & $\begin{array}{r}2.6 \\
15.6 \\
5.8\end{array}$ & $\begin{array}{l}0.2 \\
1.45 \\
0.4\end{array}$ \\
\hline E. coli .. & $\cdots$ & $\cdots$ & $\cdots$ & 4 & $\begin{array}{l}\text { Nil } \\
\text { Penicillin } \\
\text { Ceph. 87/4 }\end{array}$ & $\begin{array}{c}16-32 \\
512-1,000 \\
32-128\end{array}$ & $\begin{array}{l}2-4 \\
16 \\
4-128\end{array}$ & $\begin{array}{l}0.25 \\
0 \cdot 25 \\
0.5\end{array}$ & $\begin{array}{l}0.7 \\
0.6 \\
0.6\end{array}$ \\
\hline
\end{tabular}


cephalothin, nafcillin, and ancillin together, and finally quinacillin and methicillin.

The differences in antistaphylococcal activity were reduced in tests with a large inoculum, since methicillin and quinacillin were the least affected by inoculum size and ceph. 87/4 the most. This is probably a reflection of the resistance of the two latter compounds to staphylococcal penicillinase. In the presence of serum the activity of methicillin and ceph. 87/4 remained unchanged, that of quinacillin and cephalothin was moderately reduced, and with the other three it was considerably reduced. Thus with a large inoculum in $95 \%$ serum ceph. $87 / 4$ was the most active, but the other six compounds all showed a similar degree of activity. All the compounds tested showed a similar bactericidal action.

\section{Activity Against Methicillin-resistant Strains}

With the naturally occurring methicillin-resistant strains some cross-resistance was noted with all the compounds tested, but with quinacillin not only were the strains more resistant than with any of the other antibiotics, but the characteristic inoculum effect was absent. It has been suggested that the reason why these strains vary in their sensitivity to methicillin with the size of the inoculum is that only some of the cells are resistant to the antibiotic (Knox and Smith, 1961; Rolinson, 1961). The investigations of Barber (1964), however, suggest that variation in sensitivity of the individual cells is not the prime reason for the inoculum effect. She has shown that even in the presence of quite low concentrations of methicillin, growth on solid medium with the usual salt content is quite abnormal in that the cells tend only to grow massed together at the site of heavy inoculum and Gram-films show the cells to be swollen and irregular, suggesting a partial inhibition of cell-wall synthesis. However, if the cells are protected from lysis by use of a medium with a high salt content all the cells in an inoculum grow normally in the presence of $50-250 \mu \mathrm{g}$. of methicillin per ml. The results obtained here with quinacillin are similar to those obtained with methicillin in the presence of $5 \%$ salt.

\section{Activity Against other Penicillin-sensitive Bacteria}

It is of interest that the order of activity against other penicillin-sensitive species was by no means constant. Quinacillin was in most cases the least active, except against the relatively resistant species Str. faecalis. Ceph. 87/4 was the most active against Str. pyogenes and Str. pneumoniae and methicillin the least, except for quinacillin. With $B$. anthracis, however, a penicillinase-producing species, methicillin, shared first place with ceph. 87/4, and against $N$. gonorrhosae methicillin was outstandingly the most active, having an activity not far short of that of benzylpenicillin.

\section{Activity Against Coliform Bacilli}

None of the penicillinase-resistant penicillins had significant activity against any of the coliform bacilli. Both the cephalosporins, however, had an activity similar to that of ampicillin against $E$. coli, salmonellae, and shigellae and were more active against some strains of Proteus and Klebsiella spp.

The differences obtained with different-sized inocula are probably due to the action of antibiotic-inactivating enzymes. On this assumption different species of coliform bacilli show significant differences in their relative inactivation of penicillins and cephalosporins. Thus among Proteus spp. of some strains of Pr. mirabilis inactivate penicillins but have little or no effect on cephalosporins, whereas strains of Pr. rettgeri inactivate cephalosporins to a greater degree than penicillins. This view is supported by the investigations of Ayliffe (1964), who showed by iodometric assay that penicillinase-producing strains of $\mathrm{Pr}$. mirabilis have little or no cephalosporinase activity. Fleming et al. (1963) also reported that Pr. mirabilis was consistently negative in tests for cephalosporinase activity.

Our results with Klebsiella spp. are in slight disagreement with those of Fleming et al. (1963), since the latter found Klebsiella spp. consistently negative with regard to cephalosporinase activity, whereas Enterobacter (referred to by them as Aerobacter) were consistently positive. Our basis of classification of the two groups was similar to theirs, but we found that some strains of $\mathrm{Kl}$. aerogenes showed a marked inoculum effect with the cephalosporins and two of the strains were shown to have cephalosporinase activity by iodometric assay. However, the Enterobacter strains tested by us were much more intrinsically resistant to the cephalosporins and also had much greater cephalosporinase activity.

Strains of Pr. mirabilis, $\mathrm{Kl}$. aerogenes, and $\mathrm{E}$. coli were fairly readily rendered resistant to ceph. $87 / 4$ by serial passages in this antibiotic, but this was not associated with an increase in cephalosporinase activity. Similarly, passage of the same strains in benzylpenicillin had an increase in resistance to this antibiotic, and with $\mathrm{Kl}$. aerogenes this was associated with increased penicillinase and cephalosporinase activity. There was considerable, but not complete, cross-resistance.

\section{Clinical Application}

In relation to antistaphylococcal activity there is little to choose between any of the penicillinase-resistant penicillins, and this is borne out by early clinical trials. Klein et al. (1963a, 1963b) compared methicillin, oxacillin, and ancillin and found that all three were effective in the treatment of severe staphylococcal infection, although results with ancillin were slightly inferior to those with the other two compounds. Ancillin has the advantage that like oxacillin and cloxacillin it is absorbed from the alimentary tract (Dolan, Rhodes, et al., 1961), but Klein et al. (1963a, 1963b) regarded oral absorption of oxacillin and ancillin as unreliable and recommended parenteral administration.

The cephalosporins might be of clinical value on two fronts. First, the high antistaphylococcal activity, high resistance to penicillinase, and lack of plasma-binding suggest it might be more effective than any of the new penicillins against penicillinase-producing staphylococci.. Secondly, the cephalosporins might be more effective than ampicillin in the treatment of infections with many coliform bacilli, particularly Proteus and Klebsiella spp. The cephalosporins are also of value for the treatment of patients showing hypersensitivity to the penicillins.

\section{Summary}

The antibacterial activity of five penicillinase-resistant penicillins and two cephalosporins are compared.

Against staphylococci one of the cephalosporins shows higher activity than any of the other antibiotics tested in the presence of serum, but there is no significant difference between the other compounds.

The two cephalosporins show greater activity than ampicillin against many strains of coliform bacilli.

Our thanks are due to Dr. G. A. J. Ayliffe for some of the iodometric assays of penicillinase and to Dr. John Darrell for identifying the Klebsiella species.

\section{REFERENCES}

Anderson, K. N., and Petersdorf, R. G. (1962). Antimicrob. Agents Chemother., p. 724. 
Ayliffe, G. A. J. (1964). Nature (Lond.), 201, 1032.

Barber, M. (1964). F. gen. Microbiol. In press.

Chabbert, Y. (1957). Ann. Inst. Pasteur, 93, 289.

Cowan, S. T., and Steel, K. J. (1961). F. Hyg. (Lond.), 59, 357.

Dolan, M. M., Bondi, A., Hoover, J. R. E., Tumilowicz, R., Stewart, R. C., and Ferlauto, R. J. (1961). Antimicrob. Agents Chemother.

p. 648 .

Rhodes, R. E., Steelman, R. L., Stewart, R. C., and Ferlauto, R. J. (1961). Ibid., p. 655 .

Farquhar, J. D., Dolan, M. M., Dorman, M. G., Ziv, D. S., and Ferlauto, R. J. (1961). Ibid., p. 661 . Fleming, P. C., Goldner, M., and Glass, D. G. (1963). Lancet, 1,

Garrod, L. P., and Waterworth, P. M. (1962). F. clin. Path., 15, 328.

Knox, R., and Smith, J. T. (1961). Lancet, 2, 520.
Klein, J. O., and Finland, M. (1963). New Engl. F. Med., 269, 1019, 1074 , 1129 .

Sabath, L. D., Steinhauer, B. W., and Finland, M. (1963a). Amer. 7. med. Sci., 246,385 .

- (1963b). New Engl. 7. Med., 269, 1215.

Perret, C. J. (1954). Nature (Lond.), 174, 1012.

Richards, H. C., Housley, J. R., and Spooner, D. F. (1963). Ibid., 199, 354.

Rolinson, G. N. (1961). Brit. med. 7., 1, 125.

Rosenman, S. B., and Warren, G.' H. (1961). Antimicrob. Agents Chemother., p. 611 .

Walters, E. W., Romansky, M. J., and Johnson, A. C. (1962). Ibid., p. 706.

Yurchenco, J. A., Hopper, M. W., and Warren, G. H. (1961). Ibid., p. 620 .

\title{
Changing Age of the Menopause
}

\author{
D. J. FROMMER,* M.B., B.S., B.SC.
}

Brit. med. F., 1964, 2, 349-351

It is a common observation that adolescence nowadays occurs at a much earlier age than in the last century. Many surveys in different countries on body height and weight, bone length, and sexual development support this belief (Tanner, 1962). The average age of menarche has fallen in Great Britain from 15.5 years in 1855 (Rigden, 1870) to about 13.1 years in 1957 (Wilson and Sutherland, 1960). The average age of menarche raises the question of whether there has been a change in the average age of menopause over this period, and whether the total period of menstruation in women has increased or decreased since the last century.

There has been little research into these questions, and the present investigation was designed to throw some light on this problem.

\section{Methods}

Previous investigations into the age of the menopause have indicated that many women cannot accurately remember their age when their menopause occurred, even a few years after the event. Thus in the report of the Medical Women's Federation (1933) the number of women giving their age of menopause at 40,45 , or 50 years were very much higher than those in the years immediately preceding or succeeding these three ages. This was obviousiy due to women " rounding off" their age of menopause to the nearest multiple of five.

The method of probit analysis (Finney, 1952) was therefore adopted to overcome this source of error. This method allows the proportion of women at any particular age who have reached their menopause to be calculated without knowing the age of menopause of any one of the women. Only two pieces of information are required about any woman: (a) whether she had reached her menopause, and $(b)$ her age when giving the information concerning her menstrual state. If a sufficient number of women are used in the investigation, the percentage of women at any age who have reached the menopause can be calculated with a high degree of accuracy.

Since questioning a sufficient number of women was impracticable, the information on the menstrual history of the women in this investigation was obtained from the records of the Royal Free Hospital 1951-61. Patients were chosen according to the following criteria. (a) They appeared to be well. In cases of cholelithiasis admitted with acute cholecystitis,

* Formerly House-physician, Royal Free Hospital, London. Now Housesurgeon, Barnet General Hospital, Barnet, Herts. the patients had to have a previous history of good health. No cases of carcinomatosis from carcinoma of the breast nor any cases treated with hormones or irradiation were included in this investigation. (b) No cases with systemic or endocrine diseases-for example, diabetes mellitus-were included. (c) Patients' diseases were those which it was believed neither influenced menstrual bleeding nor the menopause, and vice versa. This was done in the hope of avoiding biasing the results.

Of the 699 cases examined, 443 were included in the present series. The rest were rejected because of lack of information in the records or because the patients did not meet the above criteria.

Women aged between 40 and 55 years were divided into 16 age-groups. Since records usually gave the age to the previous birthday only, the average age of the group was corrected by an extra half-year, since it was assumed that both the birthdays and the dates of recording menstrual state were randomly and evenly distributed throughout the year. For example, the 48-year group had a mean of 48.5 years.

The percentage of women in each age-group who had reached their menopause was found. The criterion of whether a woman was menopausal was a history of a ininimum of nine months' absence of bleeding before the observation of the menstrual state. This criterion meant that a value of percentage of women menopausal in any age-group in reality refers to a group with a mean age 9 months younger than the nominal age of the group-for example, 47.75 years instead of 48.5 years. A graph was drawn by plotting percentage of menopausal women in each age-group against the average age of each group. An S-shaped regression line for all the points on the graph and another line for the points between 45.75 and 54.75 years were calculated by means of probit transformation (Finney, 1952), and from each line a value was obtained for the age at which $50 \%$ of women reached their menopause.

\section{Results}

Of the 443 women 52 were single and 391 were married or single with children. The average number of childreiz per woman was 2.02. The various complaints for which these women attended hospital are given in Table $I$. The numbers of menopausal women at the various ages are shown in Table II.

The $50 \%$ point on the regression line (integrated frequency distribution curve) for $45.75-54.75$ years is 50.10 years (Fig. 1) 